\title{
ROLE AND POSITION OF SCIENTIFIC VOICES: REPORTED SPEECH IN THE MEDIA ${ }^{1}$
}

[En Discourse Studies, n ${ }^{\circ} 5$ (2), pp. 147-173 ]

Helena Calsamiglia \& Carmen López Ferrero

Universitat Pompeu Fabra (Barcelona)

\begin{abstract}
The purpose of this study is twofold: one, to determine the presence and function of scientific knowledge when it is required by such cases as "mad cows" disease, when the crisis breaks in the press; and two, to explore the role of scientific information through the analysis of quoted speech brought by journalists to their discourse. Citation is the most explicit form of inclusion of other-discourse (D2) in one'sdiscourse (D1). Within the framework of the theory of énonciation (Ducrot's poliphony perspective), in combination with a critical view of discourse, we analyse the following: i) the identity of agents of reference chosen by journalists; ii) the specific linguistic choices made in the pre-citation segment where the agents are introduced, that is, discourse identity procedures and use of specific verbs of communication. The study shows the proportion of scientific and nonscientific voices, the different ways of representing science agents in the process of news communication as well as the use of citation by journal writers not just to confer authority and legitimation to their discourse but to set the scene of the conflict. The scientific role is not presented as a decisive social role capable by itself of mitigating
\end{abstract}


social alarm and journalists fail to secure appropriate credibility for the scientific community.

Key words: public communication of science, media studies, énonciation, reported speech, poliphony, "mad cows". 


\section{Introduction}

In recent years the presentation of scientific knowledge, understood as scientists having regular interaction -direct or mediated- with the general public, has had a significant place in the media, apparently seeking to fill the traditional gap that exists between scientific community and people in general. As Moirand (1997) states, the press has become, in specific topics of interest, the "meeting point" for scientists with the average citizen. In fact, scientists, as a very specialized community of scholars and researchers, have throughout the $20^{\text {th }}$ century been secluded in universities and research centers, enclosed as it were within the walls of professional worlds, and lacking contact with the needs and requirements of the general public. The development of democracy and communication, in tandem with increasing consciousness of the importance of science for the distribution of political power and obtainment of greater quality of life through technology, have finally broken down the walls. This has been achieved through the generating of journalistic practices where scientists and science are represented and called upon to contribute to the formation of public opinion. This has been done not without distrust and misgiving on the part of scientists and experts but it can be said that nowadays the need for scientific culture is claimed as a social right. Nevertheless, bridging the two worlds, the world of the specialist and the world of lay people, remains a problem, not only from the cognitive perspective but also from the perspective of the representation of science and scientists outside their own domain.

Developments in discourse analysis have involved approaches to the use of language in different contexts. The one that deserves our attention is precisely the way in which progress in scientific knowledge reaches the general public in the age of information and 
communication. Scientific / academic use of language has been recognized as a specific register with its own norms, patterns and style, affecting not only terminology but ways of presentation and reasoning through particular discourse genres and procedures. No wonder, then, that the way a unit or a piece of knowledge is selected and transformed to be presented and explained to non experts can be a very rich topic of research, since it demands rigorous recontextualization conveyed through discourse procedures affecting both global and local levels of text.

In this paper we focus attention on the way in which scientific voices are referred to in the context of a particular case, involving a serious health and diet problem that has been threatening basic needs of the population in industrialized countries in Europe. This is the case of the Bovine Spongiforme Encephalopaty (BSE) outbreak -commonly known as "mad cows disease"- which in the last fifteen years has affected different countries, creating a state of social alarm and desorienting public opinion owing to the widespread consumption of meat among the population and the subsequent fear of transmission of the disease to humans.

We pursue our search at a time when, after a period of doubts and insecurity, the possibility of transmission to humans is openly stated in a session of the British Parliament, in March 1996. It is from this date on that the "mad cows" affair explodes in the media causing all kinds of diplomatic, commercial, political and social reactions. It has been a fin de siècle health crisis that has deeply worried and disturbed governments due to its consequences affecting a variety of social groups and agencies. Its importance can be gauged by the immediate attention which it received from sociologists and other analysts interested in this 
critical situation (see, for example, Daban \& Grau, 1996; Porta, 1996; Donadieu, 1997; Jasanoff, 1997; Zander, 1997 and Ratzan, 1998).

New episodes of the crisis have been again unfolding (2000-2001). The disease's genesis has been re-explained in the press in detail, especially during the last months of 2000, when new "mad cows" cases extended across several countries in Europe, mainly in France, Germany, Portugal and Spain. So the debate and the doubts still remain open, with politicians and scientists in a state of alert as to how to solve a problem that has become of great relevance due to the complex texture of its consequences.

The purpose of this paper is to analyze the role of scientists as social agents -people with something to say and do in the case under study- as they are represented in the Spanish press. Our analysis takes journalism into account as the frame of communication (macrolevel), an active domain of writing for a wide general public, with genres and conventions of its own; and, as the specific focus of analysis (microlevel), citation as a form of poliphony, a concept taken from the theory of enunciation (Bajtin -see Voloshinov 1929, Benveniste 1971/1974, Ducrot 1984). Within this framework, we identify reported speech not only through the way that grammar differentiates between direct and indirect style, but widening this view to include what in journalistic practices constitutes a continuum of reference to "other" voices which pragmatic perspective has taken into account (Reyes 1993/1994) and in relation to journalistic practices (Waugh 1995, Méndez 1999a, 1999b). We consider both levels as a whole from a critical perspective that favours the view that citation means managing other's words to convey and serve the purpose of the writer, giving a slant to what is said. This contrasts with other views, such as those presented in journalism 
training, arguing that citation not only makes the writer's discourse more objective and credible, but frees him/her from any responsibility.

\section{Background information: brief history of the BSE case}

The object of our study is scientists' reported speech in a corpus of news which reports the popularly known "mad cow" disease, technically called Bovine Spongiform Encephalopathy. Although the period we analyze in the present paper is the first erruption of this affair in the press in 1996, we emphasize the relevance of this scientific/social topic as a recurrent one in the media. But there are scientific topics that enjoy punctual or acute interest ("patrón de interés puntual o agudo", Informe Quiral 1999: 74), meaning that they generate a great amount of news in a brief period of time. Such is the case of the beginning of the "mad cows" affair, generating 75 news items in the period of March-April 1996 in the most widely read general Spanish newspapers.

In order to put the news in context we need to refer to some key scientific data on Bovine Spongiform Encephalopathy as a degenerative pathology of the brain. The origins go back to an infection known as scrapie, identified in 1732 in sheep and goats. In 1920, the human disease Creutzfeld-Jakob (CJD) is identified, with intriging similarities to scrapie. In the 70's, Stanley Prusiner, 1997 Nobel Prize winner in Medicine, identifies the agent which causes the disease. It is called prion, a special variant of a protein (healthy or diseased) found in all brains. The altered protein (prion) cause changes in the normal proteins, and it triggers a chain reaction which finally leads to the brain disease. In 1985, in Great Britain, Bovine Spongiform Encephalopathy (BSE) was described as a disease closely related to 
scrapie. Three years later, $B S E$ is related to the ingestion of animal feeds derived from meat and bones of infected sheep.

Political data are also relevant to understand the case. We will note the following events: in 1986 the British government officially declares BSE's existence. From then on, various actions are taken by the government: organic animal feeds are forbidden, an expert report on BSE is demanded (finally published in 1989), animals are slaughtered. But people are persuaded by the government agencies not to worry about eating meat. There is widespread conviction that there is no relation at all between human and animal brain pathologies. At the same time, powerful economic interests emerge in the face of an uncertain but openly predicted possible crisis of enormous consequences. The British Government officials of different ministries are responsible for indecision and lack of transparency.

In 1990, a Committee appointed by the British Government is set up to monitor the incidence of the disease. It consists of experts in contact with a team of medical researchers in Edinburgh. On March 20, 1996 the British Health Secretary informs parliament that a variant of the human encephalopathy (Creutzfeld-Jakob) could be related to BSE. The evidence is not clear but generates widespread bitter conflict between institutions, government, commercial organizations and food industry, causing diplomatic relations to be broken off and alarming the average citizen. The focus of the crisis is Great Britain, but other countries in Europe are also under the threat of the disease and its transmission across species. This conflict is taken up by the media where scientific information is mixed with political statements, commercial reactions and citizens demanding clarification. 
As regards scientific progress in brain pathologies, in spring 1996 there were some significant scientific advances which reached the mass media. But the scientific community was going at its own pace in the midst of the press storm. In fact, research on such a rare disease as Creutzfeld-Jakob had been very sparse, only receiving a boost after the BSE outbreak in cattle. Nevertheless, fourteen years after the bovine disease was first identified, ultimately causing 92 human victims -mainly in Great Britain-, lack of scientific certainty and political dithering undermined European consumers' confidence.

During the period studied in our paper, March and April 1996, two scientific articles were published; these were not generated by the sudden crisis and consequently they were not intended to provide a clear-cut response to people's concerns. The scientific information provided by these two articles was taken up in the news report in our corpus. The first article was a medical report produced by the Edinburgh team: "A new variant of Creutzfeld Jakob disease in UK" by R.G. Will, J.W. Ironside et al., published in the medical magazine Lancet on April 6, 1996. It contains no clear proof but considers that exposure to BSE is the most plausible cause for transmission of the disease across species. The second article referred to the ongoing resarch on the "prion" protein, after Prusiner's findings in the 70's. The article appeared on April 25, 1996, in the scientific magazine Nature, written by D.C. Krakauer, M. Pagel, T.R.F. Southwood and P.M. de A. Zanott and entitled "Phylogenesis of prion protein". The first article was leaked to the press by the governmental committee before publication in The Lancet. The second was the direct source of information appearing in the press. 
The press presented the facts summarized here, their interest sparked off after the British parliamentary session in March 1996, mentioned above. The media brought into their discourse reported speech from different sources which supply reference points for the interpretation of the facts. This use of reported speech is the object of our study.

\section{Broad context of the study: discourse and media}

The approach that we take considers reported speech in the context in which it appears. The case under study has newspapers as its context or domain. Thus, in order to control the object of our study we can locate and define it in the light of what van Dijk (1988) and Charaudeau (1997) have proposed concerning different aspects of informative discourse in the press. To begin with, Charaudeau provides a general semiotic approach from the perspective of the communicative contract, as it is represented in figure 1:
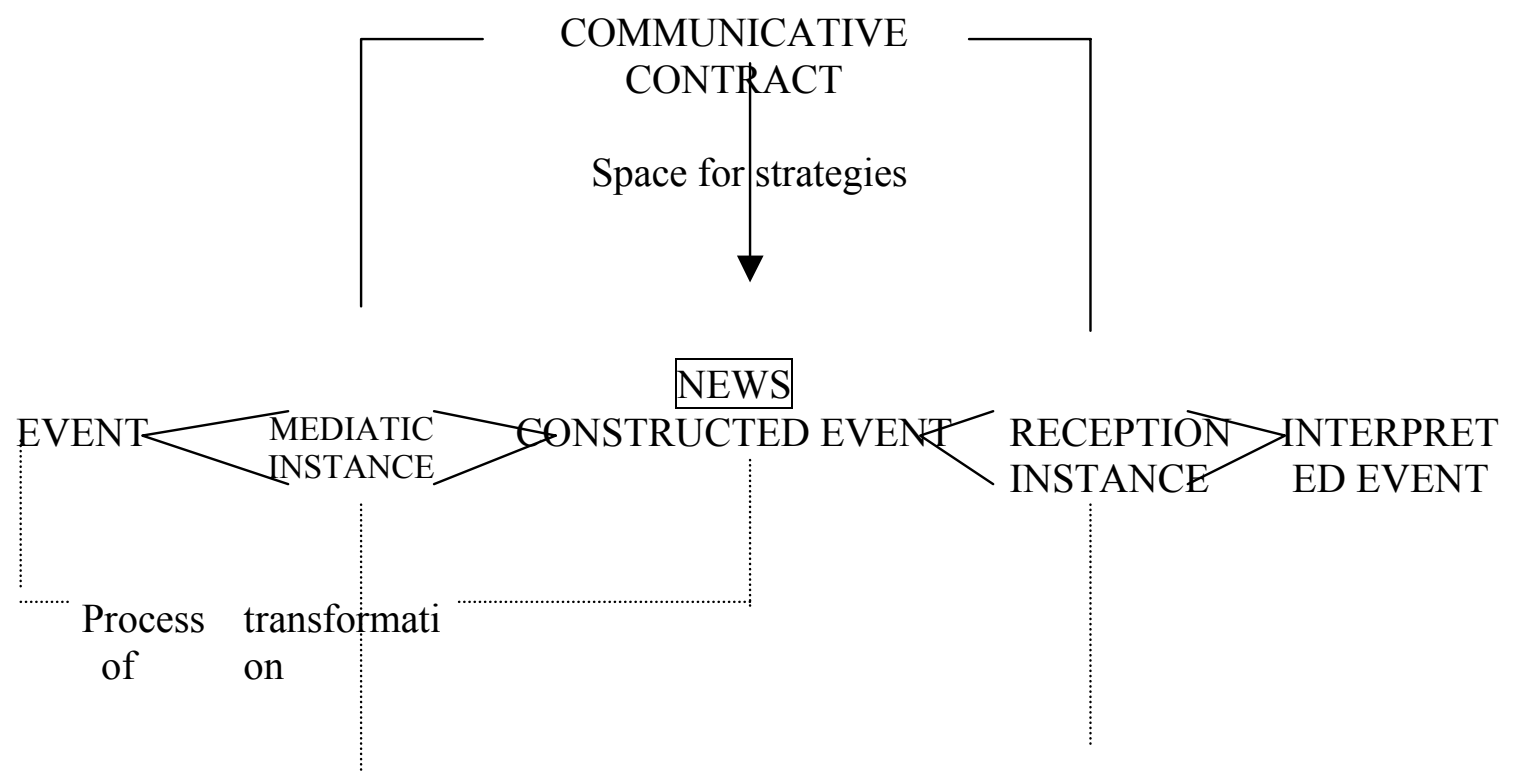

Process of transaction

Figure 1. Charaudeau (1997: 72) 
The event in the media goes through a process of transformation that results in the construction of the event by its representation in words. So the process of transaction allows for strategies within the frame of the communicative contract.

The discourse modes of a mediatic event are viewed as follows:

DISCOURSE MODES OF A MEDIATIC EVENT
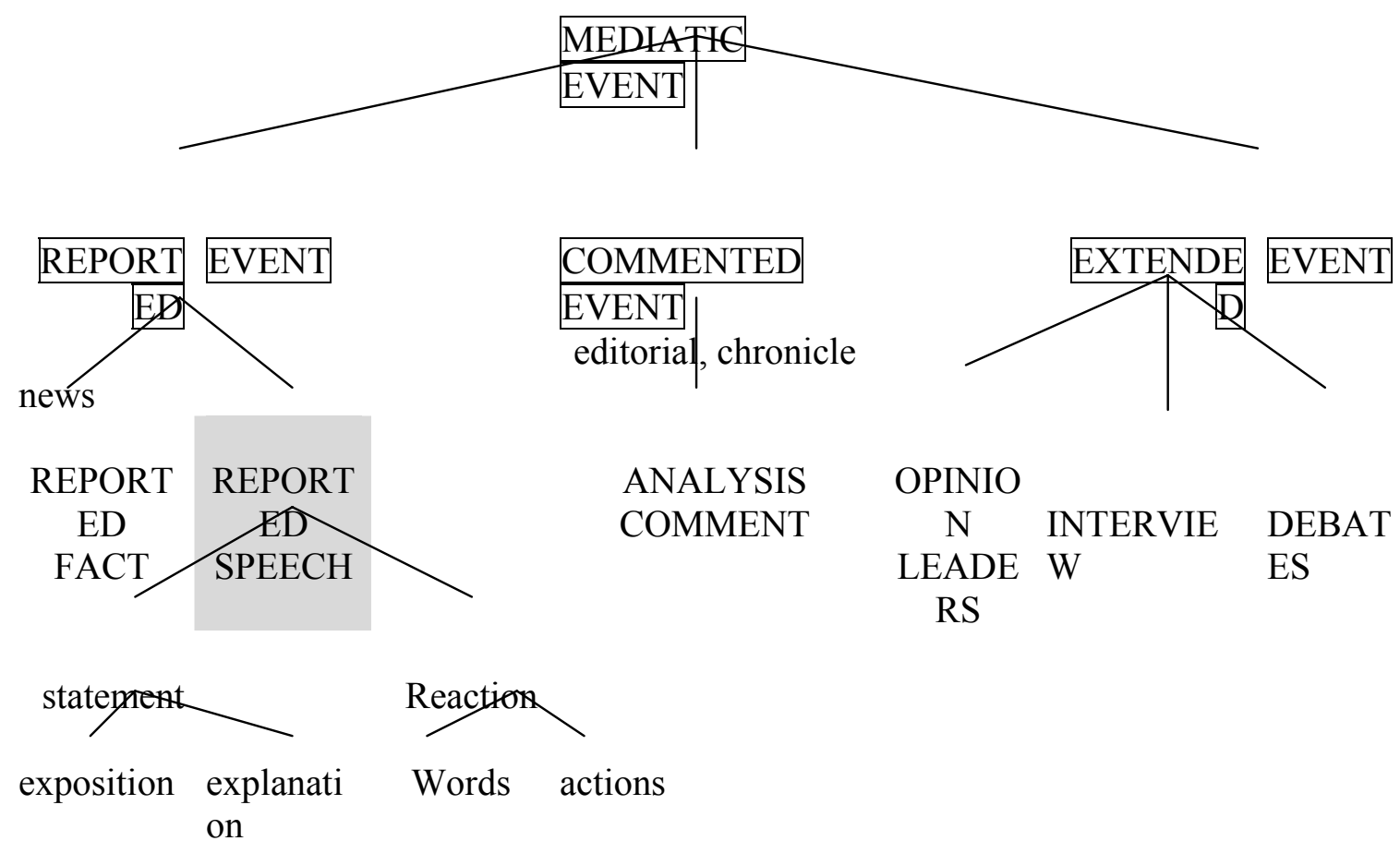

Figure 2. Charaudeau (1997: 168)

Given the discourse modes of the media event, schematized by Charaudeau, it is clear that the object of our study is the first phase, that of the reported event, where what is being said predominates over reference to fact. 
If we rely on Van Dijk 's schema for the superstructure of news in the press (figure 3) we see that if the media story is made up of situation and comments, the situation in the "mad cows" case is an oral episode that triggers a variety of comments (oral reactions) from different sources. As the first focus of attention is a statement by the British Health Minister and the subsequent debate in the House of Commons, it is a case where words become the core of information. This was the origin of the sensational treatment of the affair in the press.

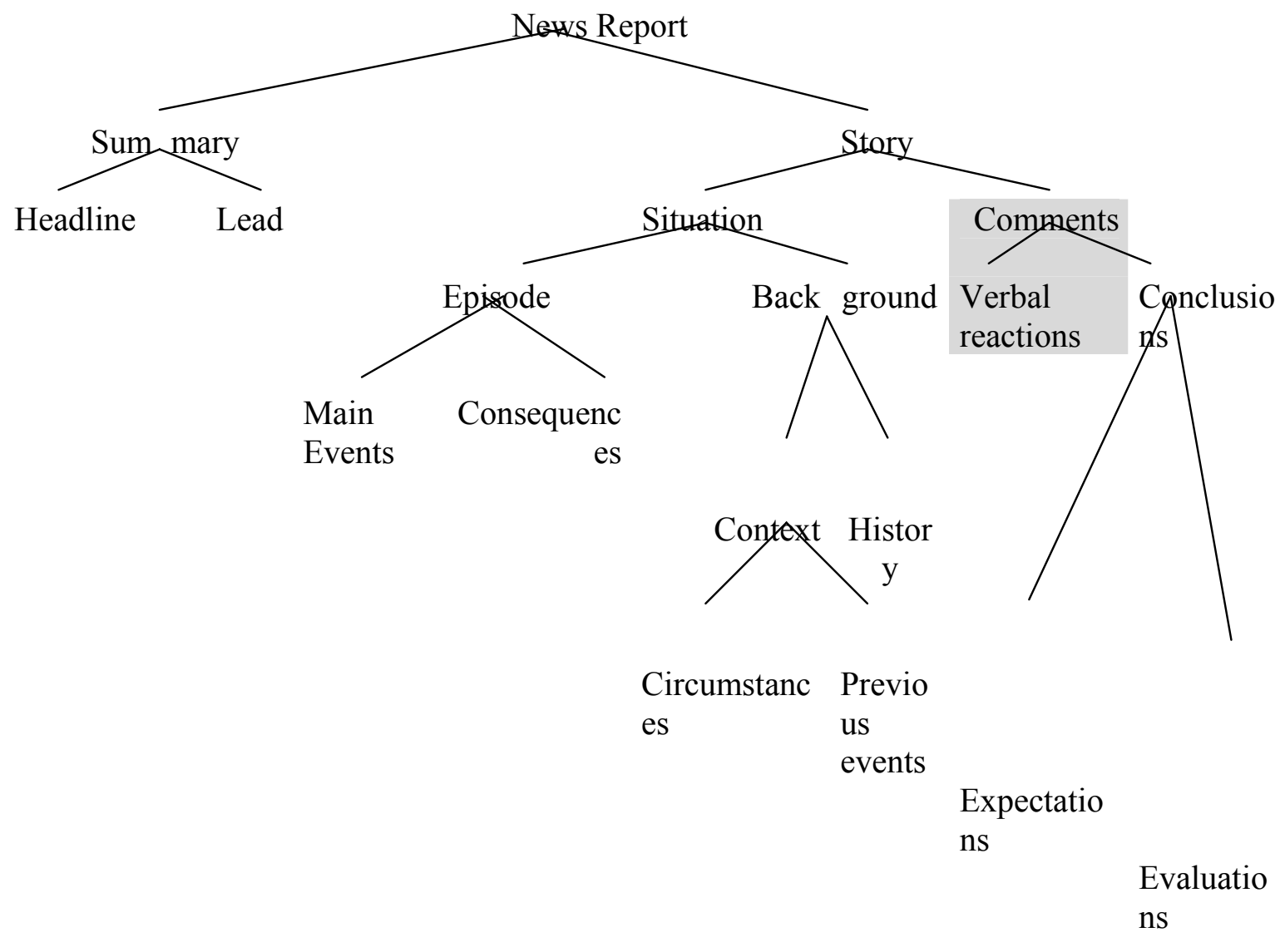

Hypothetical structure of a news schema

Figure 3. Van Dijk (1988:55) 
At the microlevel, journalistic practices have established conventions on procedures of citation because of its constant presence in the news. In style books we consistently find instructions on the proper way to present citation. As an example:

"All alien words, statements or opinions transcribed literally in an informative text have to be signaled with quotation marks, without changing the sense or intention with which they were uttered[...]. The author will always be identified, through the proper name or any other characteristic that supports, justifies or gives authority to his/her words. The identification will be done at least once, in the begining, in the middle or at the end of the transcribed sentence." (ABC 1993:52; authors' translation)

Prescriptive guidelines for journalists stress the use of citation to give authority and legitimacy to what is said through the strict (literal) quotation of words spoken by others. It is one of the procedures by which to obtain credibility for the facts under comment as well as one of the means of certifying knowledge of what is being said. Literal quotation is intended to be objective knowledge, far removed from the subjectivity of the journalist.

\section{Theoretical framework}

Different studies have been carried out in the last decade on specific aspects of reported speech from a variety of perspectives, about various domains and languages (see, specially, the compilation of articles of Lucy (1993) and Janssen and Van der Wurff (1996), including Haverkate's on reported speech in Spanish literary works. We have based our approach on the conception of the énonciation theory as initiated by the soviet scholar Bajtin (1979), formulated by the French linguist Benveniste $(1971,1974)$, developped by different representative authors as Kerbrat-Orecchioni (1980), Authier Revuz (1982), Ducrot (1984), Maingueneau (1987, 1991,1993) and applied to journalism as Waugh (1995) and Méndez (1999a,1999b). In its first formulation the theory puts forward the existence of a Speaker that actualize the virtual system of language (énonciateur) in relation to a Hearer 
(énonciataire), two axes from which choices of textual items are made and from which a particular variety of text (énoncé(s) is derived. The two main characters of the communicative act (énonciateur, énonciataire) are present in the text through different kinds of lexical and deictic traces whose interpretation gives the key for a degree of personal and interpersonal implication. Most of the studies in this framework have focused on the emergence of subject in texts,making its basic assumption on the fact that the subject is built through the process of énonciation. Ducrot, on the line of the fundamental heteroglossy of language as it is claimed by Bajtin, breaks the assumption of a one to one relationship between Speaker and text. His hypothesis is that the Speaker can be unfolded in several voices (polyphony) and postulates to make a distinction between

a) the text author or empirical subject (pre-discursive identity).

b) the construction of the discourse subject (a voice created in text)

a) the triggering of other voices which contribute to the perpectives adopted by $b$ to build a particular position.

In every situation of énonciation the author creates a voice taking a position, choosing a role according to the possible addressees. This position and role can be enriched and precised by the inclusion of different other voices that $b$ adopts to confirm or contrast the position taken. The interest of the discourse analyst is in $b$ and $c$, that is, in the particular way the author chooses to be concerned with the text (degree of incorporation, modality -voice-building) and in the variety of other voices that can be integrated into the discourse. One's own voice can be unfolded, as for example in the case of irony. Other voices can be included, either explicitly, through citation, or implicitly, through what is called concealed citation. The identification of the presence of various voices and the way they are called up in the text is 
one of the most challenging analitical problem to find the line taken by the discourse subject in any text.

This theoretical framework allows for considering quoting as a strategy of the writer not only to convey information but also to give an orientation to the text through the choices made in the linguistic constituents of the quoting procedure.

An integrated approach to a specific discourse procedure such as citation would appear to be very useful in accounting for the sense, direction and effects of the insertion of words from different sources into the main discourse of the journalist. We address the following questions: what is the role of scientific voices in cases where they are entitled to talk? Which are the forms of quoting? Is quoted speech a way of absolving journalists from responsibility or a means of orientating their position on the topic of reference? How is all this managed in a situation of crisis? To give an answer to the questions that arise in the study of the use of this discourse procedure we combine different levels:

b) the description of grammatical construction and markers of explicit citation (Girón Alconchel 1989, Reyes 1993, Maldonado 1991\&1999);

c) the function accorded by the theory of énonciation to reported speech as a form of polyphony;

d) the interpretation accorded by critical discourse analysis to the representation and presentation of agents in reported speech (Caldas-Coulthard 1994, Van Leeuwen 1996).

From this perspective, the three levels contribute to a discoursive explanation that includes the written press context, the discourse functions accomplished and the linguistic units 
chosen. Grammars have defined explicit citation in terms of direct / indirect styles. Nevertheless, it is interesting to note, as observed by scholars like Méndez (1999) who study quotations in the press, that the clear-cut differentiation between the two main styles is not entirely relevant for the journalistic domain since there are a number of different ways of bringing words from others by combining traits of direct and indirect style -considered as the basic axis defining reported speech. The increasing presence of words from different sources when conflict is projected in news in the press gives rise to a variety of ways of formulating them. If the study of citation was based traditionally on its occurrence in literature, where free indirect speech typically found, its use in other contexts (daily conversation or newspapers, for example) leads to the incorporation of other parameters in the identification of citation formulae.

Taking into account that we are dealing with written data, we can distinguish different styles:

- direct citation: there is a fracture between the syntax of $\mathrm{D} 1^{2}$ and $\mathrm{D} 2$ because it entails the maintenance of two different deictic centers (affecting tense, space and time adverbs and person-reference words), as a result of the two different enunciations being put in relation one to another; the two segments are connected through juxtaposition and they are signaled by graphic markers such as “:”

- indirect citation: there is only one discourse, D1, with a single deictic center, a subordinate clause introduced by a conjunction, and the correspondent agreement of tenses.

- integrated citation: it has the form of indirect citation but with segments -of greater or lesser extension- signaled as being cited directly/literally with clear graphic or 
typographic marking, mainly with " $\mathrm{X}$ " or marked fonts (boldface or italics). This type of citation allows for mixing syntactic traits of direct and indirect style, a phenomenon rejected by grammarians as not well formed but frequently used by journalists.

- inserted citation: words of W2 are brought into the main discourse by means of markers such as "según X" or "para X" "in the words of X", " according to X" which have the function of assigning explicit words to a particular agent (literal or non literal, depending on the use of graphic signs of quotation) without any communicative verb.

The narrative style of the news makes the appearance of direct speech rarer while the rest are very frequent, with a broad and loose acceptance of either one or two deictic centers.

Pragmatically speaking, the idea that is brought to the fore is that in any of the explicit occurrences of D2, in any of the forms referred to here, the possibility of obtaining strictly the same original sense through literality is seriously called into question. Even if the exact words are reproduced, they are extracted from the original context and are placed in a new context that can modify the sense. That is the conclusion drawn by Reyes (1993) and by Caldas-Coulthard (1994) and suggest we should question a maxim apparently accepted by the standards of journalism: that explicit quoting means fidelity to the text. As it is argued:

"Direct style is often opposed to indirect style, somewhat ingenuously, saying that it seeks to reproduce literally the cited words. It would be more exact to view it as a sort of dramatization of a previous expression, rather than a totally similar one. In other words, it is no more or less reliable than indirect speech: they are two different strategies to refer to previous speech." (Maingueneau 1987: 60; authors' translation) 
The presence of different voices evoked in a text leads us to consider the polyphonic character of news in journals (Ducrot 1984, Authier 1982, Maingueneau 1987). In that sense, the idea of one text / one voice is not at issue. Rather, different voices are assumed or directly evoked by the writer, who builds the representation of a world of reference through a combination of a variety of voices. The relative weight, frequency and value of the different voices will, by means of the observation of the empirical data, provide us with a profile of protagonism taken on by the social actors whose words are called upon in relation to the topic.

Finally, studies from a critical perspective of the ways social agents are presented (CaldasCoulthard 1994, Van Leeuwen 1996) allow us to question the neutrality of the writer and pick out the argumentative trend that arises from the fact of choosing who is cited, how he/she is represented, what is cited and for what purpose.

\section{Delimitation of the linguistic-discursive object: form and function of explicit citation}

Even if we are conscious that voices can also be integrated in more subtle ways, considered by various scholars as "hétérogénéité constitutive" (Authier 1982), as "narrative mode of citation" (Charaudeau 1997) or as "echoes, hidden citations" (Reyes 1994), in this paper we are concerned with explicit citation. This kind of citation consists of the main text (D1) and the quoted text (D2). D1 is sequentially the point of departure from which the writer (W1) designs the development of his/her own discourse. Before inserting the cited voice (2), W1 introduces a preparatory frame (Girón Alconchel 1989), which is formed by: 
a) The presentation of the identity of the cited voice. It involves the presentation of the agent, by such linguistic means as names, proper names, titles or honorifics, designation of status and public position, relational adjectives, etc. Any of the choices made are significant.

b) The communicative verbs (verba dicendi) that W1 attribute to the voice of cited agents (W2).

c) Other elements that are not necessary but possible: narratives, descriptions, modalities...

The frame is the presentation of $\mathrm{W} 2$ made by $\mathrm{W} 1$, where $\mathrm{W} 1$ is responsible for creating a new context for the cited words. That is why we focus on this precise portion of citation, the pre-citation, which plays the role of interface between D1 and D2.

For the study of the pre-citation segment we have drawn on the suggestions in the Van Leeuwen's schema (1996:66 ) concerning different modes of inclusion of agents:

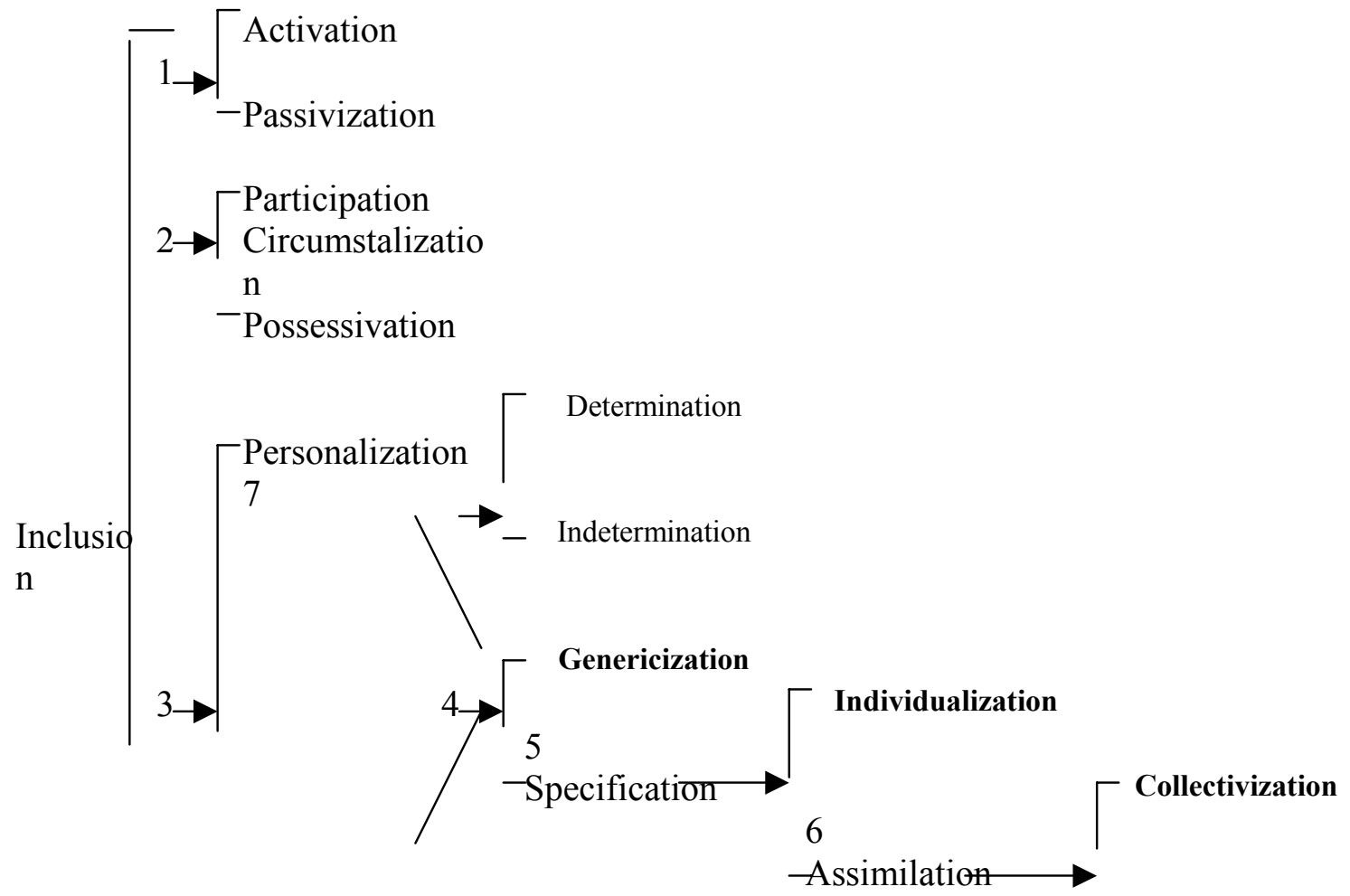




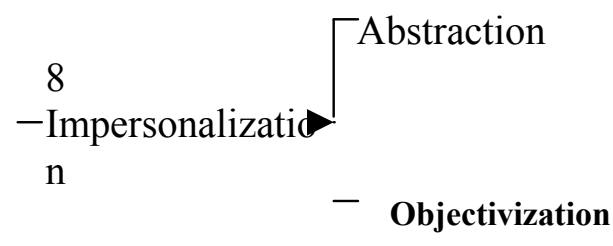

Figure 4. The representation of social actors in discourse: inclusion system network (adapted from Van Leeuwen 1996)

In the framework of Van Leeuwen's description, we have considered the five categories stressed by boldface font in figure 4: a) genericization, b) individualization, c) collectivization, d) aggregation, and e) objectivization. In our data, those are the most frequent forms of representation of members of the scientific community.

Van Leeuwen (1996:46) considers an important factor in the presentation of social actors the choice between generic and specific reference: actors can be represented as "classes" (genericization) or as "specific" identifiable individuals (specification). The specification can be singular (individualization) or plural (assimilation). Examples of generic forms in our corpus are forms such as "scientists", "doctors" without a specific reference to a concrete group of experts.

The process of singular specification in the corpus is expressed by authority voices (individual scientists); as for assimilation, Van Leeuwen (1996:49) distinguishes two major forms: aggregation and collectivization. Aggregation quantifies groups of participants, treating them as "statistics" (ex.: "a number of critics"), collectivization does not. In collectivization, social actors are presented as "community", as a homogenous, consensual group; this is the case, for example, of "WHO experts" in our corpus. 
Genericization, individualization, collectivization and aggregation are four personalized forms in the process of agent representation. On the contrary, objectivization is a form of impersonalization, also frequent in our corpus and realised by metonymical references, such as "texts".

The five forms considered can be determined or undertermined. Thus, we have considered the Van Leeuwen's distinction determination / indetermination:

"Indetermination occurs when social actors are represented as unspecified, "anonymous" individuals or groups, determination when their identity is, one way or another, specified. Indetermination is typically realised by indefinite pronouns ("somebody", "someone", "some", "some people") used in nominal function [...]. Differentiation explicitly differentiates an individual social actor or group of social actors from a similar actor or group, creating the difference between the 'self' and the 'other', or between 'us' and 'them'. (pp. 51-52)

As for the reporting verbs related to the agents, while it is necessary to accept the wide variety of "verba dicendi" and the impossible task of classifying them ${ }^{3}$, it is also clear that they can confer a content-oriented trend or an evaluative trend. We find interesting suggestions in the way Thomas \& Hawes (1994) and Hyland (2000) have indicated types of content or evaluative approaches channeled through the choice of verbs of communication (see Figure 5):

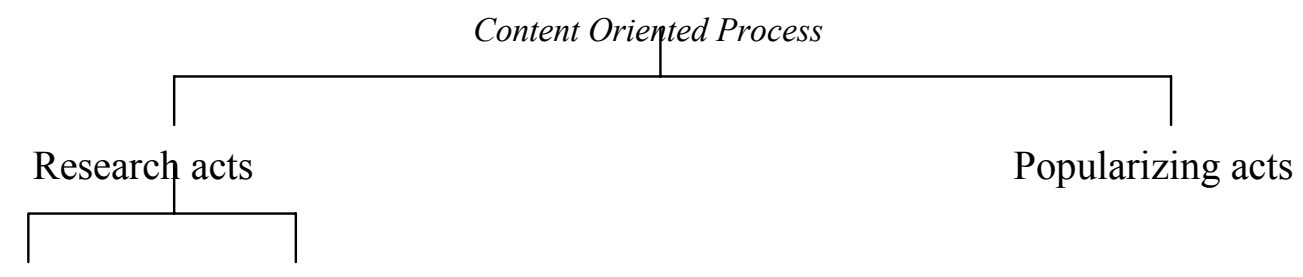

Findings Procedures 


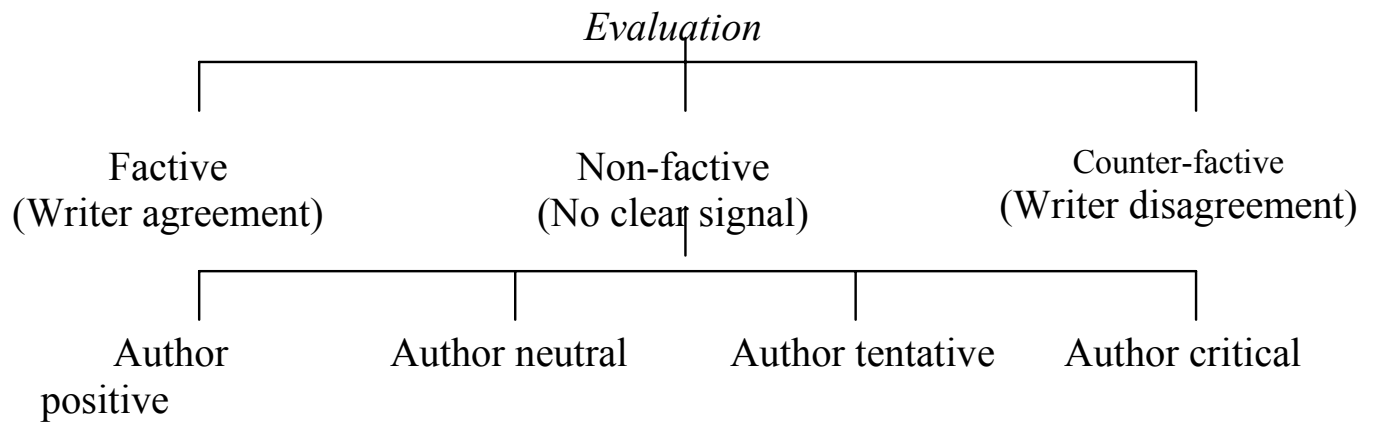

Figure 5. Critical analysis classification of reporting verbs

In content oriented process, verbs related to findings (observe, discover, notice, show) or to procedures (analyse, calculate, describe, assay, explore) refer to research acts of science agents. Popularizing acts (explain, describe, compare, define, exemplify) refer to clarify and facilitate understanding of specialized concepts.

Evaluation verbs "allows the writer to ascribe a view to the source author, reporting him or her as positive (advocate, argue, hold, see), neutral (address, cite, comment, look at), tentative (allude to, believe, hypothesize, suggest), or critical (attack, condemn, object, refute)." (íbid, 2000: 28).

Through an accurate analysis of the framing of the quote we can indicate the interpretive cues that are given by the writer, because of the important role of choices in determining the argumentative orientation :

- choice of type of agent (conveying authority or credibility in a particular domain);

- choice of his/her representation in discourse (as an individual or a collective, determined or undetermined, personalized (author) or objectivized (text), etc.;

- choice of reporting verb (locating the agent in a position towards the topic). 
In the case of the "mad cows" disease, types of agents that are called upon can tell us which are the sources that are presented as more relevant, those of the scientific community or those with political or civico-social standing. This is a sociological distribution that gives external configuration to the voice. But their representation is achieved by internal configuration through language use; the image of the agent is constructed and related with a specific reporting verb. Our claim is that close analysis of the pre-citation segment, the frame of the cited words, will give us important clues to the interpretation of the role and position of scientific voices.

\section{Corpus and data treatment}

We have based our study on a corpus of 75 news items from 6 different newspapers: $L a$ Vanguardia, El País, El Mundo, El Periódico, ABC and Avui. These are the most widely read general newspapers in Spain (Avui circulates in the Catalan-speaking area). The news items considered were published in March and April 1996 (between March 22nd and April 27, 1996, to be exact ${ }^{4}$ ). This corpus contains the "reported speech" in the process of communication of news (Charaudeau 1997).

The 75 news articles (D1) provided the 445 reporting structures (D2) that constitute the microlevel units analyzed, both reported speech from non-scientific voices (349 statements) and from scientific voices (96 statements). We have focused the present study on the 96 scientific reporting structures, $21.57 \%$ of the reported speech in the corpus selected. 
We compiled an extensive database to allow us to study quoted speech both from a quantitative and a qualitative point of view. Every citation has a corresponding register which details information on the macrolevel of discourse (newspaper, press genre, press section, news author) as well as on the textual microlevel (identification of W2, form of citation, reporting speech choice, text of citation).

\section{Analysis}

After the delimitation of the object of our study and the presentation of the corpus, in the present section we proceed to study the role and position of scientific voices in the "mad cows" affair as they are communicated via the Spanish press. First we analyze the results of the study of the "quoting frame" of scientific citations: representation of agents and choice of reporting verbs. Then we present a brief analysis centered on the contrast between scientific and non-scientific reported speech; this contrast allows us to obtain relevant data which helps to explain the role and position of scientific voices. 


\section{A. Analysis of scientific voices}

We have divided our corpus into three chronological information "peaks" or phases, given the concentration of the news around each peak, and the silence or "pause" in between. Note that in phase 1 and phase 2, sources from scientific articles are not available, the source being governmental agencies that interpret the report issued by the scientists (see section 2). Only in phase 3 is the information related to an article on the prion (from the microbiology field) which appeared in Nature.

The three phases, including the percentage of citations, are the following:

Phase 1: $22-24 / 3 / 1996(44.30 \%)$

Phase 2: 28-31/3/1996 (33.04\%)

Phase 3: 24-27/4/1996 (22.60\%)

For every phase we will give some representative examples of the dominant scientific voice and of the associated reporting verbs, so that we are able to see where there are modulations of the general stance detectable in the distribution of the different ways of representing scientific voices (Van Leeuwen, 1996).

The following table presents a summary of the process of representation and position of scientific voices in the different phases considered: we present the most frequent forms of representation of actors and the reporting verbs associated with each kind of representation.

\begin{tabular}{|c|l|l|}
\hline \multicolumn{1}{|c|}{ Phase } & \multicolumn{1}{|c|}{ Representation of identity } & \multicolumn{1}{c|}{ Reporting verbs } \\
\hline 1) $22-24 / 3 / 1996$ & a) Genericization & a) Tentative \\
& b) Collectivization & b)Positive \\
\hline
\end{tabular}




\begin{tabular}{|c|c|c|}
\hline 2) $28-31 / 3 / 1996$ & $\begin{array}{l}\text { a) Individualization } \\
\text { b) Assimilation: collectivization } \\
\text { and aggregation } \\
\text { c) Objectivization }\end{array}$ & $\begin{array}{l}\text { a) Research }+ \text { markers } \\
\text { b) Controversial: positive, tentative } \\
\text { c) Positive, research }\end{array}$ \\
\hline 3) $24-27 / 4 / 1996$ & $\begin{array}{l}\text { An only source represented as: } \\
\text { a) Collectivization } \\
\text { b) Objectivization } \\
\text { c) Individualization }\end{array}$ & $\begin{array}{l}\text { a) Research, tentative }+ \text { markers } \\
\text { b) Research } \\
\text { c) Popularizing + markers }\end{array}$ \\
\hline
\end{tabular}

Table 1. Forms of representation of identity and reporting verbs

We have characterized every phase with a title that shows the differences found between the communication of scientific knowledge in each case: from caution (tentative point of view) to assertiveness (positive perspective) in the first phase; diversification of the scientific voices and their representation (individualization, assimilation and objectivization) in the second phase; presence of an only source in the third phase, which is collectivized, individualized or objectivized.

\section{A. 1. First phase: caution versus assertiveness}

The systematic observation of citations in this first phase shows that social actors are represented by forms of genericization and collectivization (a form of assimilation). Scientists are presented as a class in genericization without a specific referent, as we can see in the following examples ${ }^{5}$ : 
(1) Los científicos dicen ahora que esos cuatro años fueron decisivos para que se saltara la barrera de las especies y se desarrollara una versión humana de la enfermedad. ( $L a$ Vanguardia, 23/03/96)

(1) Scientists now say that those four years were decisive in the breaching of the species barrier and the development of a new human version of the disease. (La Vanguardia, 23/03/96)

(2) Los médicos creen saber distinguir estos últimos "porque se producen en menores de 42 años presentan una analítica diferente desde el punto de vista anatomopatológico y son de evolución más lenta, algo más de 20 meses. (El País, 23/03/96)

(2) Doctors believe they can distinguish the latter "because they occur in people less than 42 years old, are analytically different from an anatomo-pathological point of view, and are slower to develop, taking somewhat more than 20 months". (El País, 23/03/96)

"Scientists" and "doctors" are genericized, and so symbolically removed from the readers' world of immediate experience, treated as distant class. As we will see in 7.B, other types of voices, non scientific voices such as politicians, are not genericized.

When the process of genericization is chosen, the scientific cited words in press are presented by a tentative verb, such as "believe". This type of reporting verb is one of the most frequent verbs used in our corpus, always associated to a generic or an assimilate voice, as examples 1 and 2 shows, to express caution in front of a critical situation that relates both to social perception and to limitations of scientific knowledge.

On the other hand, in this first phase scientific voices are also reported as members of an international organization (World Health Organization, WHO), as a form of collectivization: 
(3) Per la seva part, experts de l'OMS van assegurar ahir que no veuen justificació científica per prohibir la importació de carn de boví procedent de Gran Bretanya. (Avui, 23/03/96)

(3) For their part, WHO experts yesterday assured ust they saw no scientific justification for prohibiting meat imports from Great Britain. (Avui, 23/03/96)

In this example 3 we can see that WHO experts are presented as a "community", as an homogeneous, consensual group which have the responsibility of evaluating findings in science and its consequences for the general public. WHO experts are put under a process of collectivization. His influence and political representation in society justifies the reporting verbs chosen to present their speech: verbs associated with this collective are always positive ("assure"), a type of reporting verb which is never used in our data to introduce scientific class. The collective of WHO scientists is characterized by his assertiveness versus the caution showed by scientists in general.

As we have said, in the computation of reporting verbs, the verbs more frequently used in our corpus are positive ("assure”), popularizing acts ("explain”), neutral ("say”, "state”) and tentative ("believe”). In this first phase - as in the other two-, positive evaluation of facts are never in the generic voice of science. Assertiveness is always related to political representation.

All these observations are completed by the content of the quotations, which shows two distinct trends: the medical experts show "caution" about their findings (ex. 2) while the organization reveals "assertiveness" in mitigating social alarm (ex. 3). Knowledge of the context of these news items is crucial, because scientific information is channeled by governmental agencies, after debate in parliament. So, in this first phase, the dominant source is homogeneous and it is presented in agreement. 


\section{A. 2. Second phase: diversification of scientific voices}

In the second phase of the event, more voices are called upon to inform about "mad cows" disease. Dominant scientific voices are reported in three different modes: individualization, assimilation and objetivization.

As for individualization, the linguistic form of presentation is through determination by use of name and surname, professional identity and institutional status and origin, as example 4 shows:

(4) Según afirma Stanley B.Prusiner, profesor de Neurología y bioquímico en la Universidad de California, en el Scientific American, "es una teoría, pero puede que los cambios estructurales de la proteína alterada, el prión, sean también responsables de otras enfermedades degenerativas más comunes como el Alzheimer. Y esta posibilidad no debe ignorarse". (El Mundo, 28/03/96).

(4) According to Stanley B. Prusiner, a teacher of neurology and biochemistry at the University of California, in the Scientific American, "it's a theory, but it may be that structural changes in the altered protein, prion, might also be responsible for other degenerative diseases more common than Alzheimer. And that possibility should not be ignored." (El Mundo, 28/03/96)

In this phase, as in the first one, it is noticeable that reporting verbs are distributed differently depending on the identity. Individual authorities are presented frequently with markers of reported discourse such as "for", "according to" ("para", "según" in example 4), contributing thus to the neutrality or distance established by the writer. Reporting verbs used 
to introduce authorities are above all research verbs -"describe" ("describir"), "conclude" ("concluir")-, not very frequent in the corpus. Two examples of this kind of structures are the following 5 ("described") and 6 ("concludes"), with individualized voices ("Vincet Zigas" and "Carleton Gadjusek" in example 5, "Jeffrey W. Almond" in example 6):

(5 )Vincet Zigas, del Servicio de Salud Pública de Australia y Carleton Gadjusek, del Instituto Nacional de la Salud de EEUU, describieron en 1957 cómo miembros de una tribu de Papúa Nueva Guinea sufrían una enfermedad mortal caracterizada, primero, por la pérdida de coordinación y, después, por demencia. (El Mundo, 28/03/96)

(5) Vincet Zigas, of the Australia Public Health Service and Carlton Gadjusek of the National Health Institute of the United States, described in 1957 how a tribe in Papua New Guinea suffered a lethal disease characterized firstly by loss of coordination and then by dementia. (El Mundo, 28/03/96)

(6) El científico Jeffrey W.Almond concluye en un artículo publicado en el British Medical Journal: "Es obvio que la forma de presentación de la ECJ en Gran Bretaña, en comparación con otros países libres de la enfermedad de las "vacas locas", es una causa que debe ser estudiada". (El Mundo, 28/03/96)

(6) Scientist Jeffrey Almond concludes, in an article published in the British Medical Journal that "It is obvious that the form in which ECJ presents in Great Britain, in comparison with other countries free from "mad cows' disease", is a cause which should be studied." (El Mundo, 28/03/96)

As far as assimilation is concerned, collectives are presented in a general determined or undetermined form and are now dispersed across different fields (neurology, veterinary medicine, etc.), institutions (hospitals, health services, etc.) and countries (Great Britain, 
United States of America, Australia, etc.). It is not the case, then, of a generic scientific reference as it was during the first phase but of heterogenous collectives of scientists: in example 7, "Las autoridades sanitarias" and "los propios médicos del hospital de Canterbury" have specific references:

(7) Las autoridades sanitarias y los propios médicos del hospital de Canterbury, donde murió Anne Pearson, no han querido hacer comentario alguno sobre el caso, más allá de decir que "es imprudente especular sobre cómo la víctima contrajo el CJD, porque su caso está siendo todavía estudiado en un laboratorio de Edimburgo y no hay conclusiones definitivas". (La Vanguardia, 30/03/96)

(7) Health authorities and the doctors themselves at the Canterbury Hospital where Anne Pearson died did not wish to make any comment concerning the case, beyond saying that "it is unwise to speculate over how the victim contracted CJD, as her case is being studied at the Edinburgh laboratory and there are no definitive conclusions." (La Vanguardia, 30/03/96)

Forms of aggregation are also frequent in this phase, showing the different points of view in the groups of scientists: in example 8 the determiner "some" ("Algunos") in front of “others" ("Otros", "Y otros") signals different groups of experts which did not agree in the scientific explanation of the phenomenon:

(8) Algunos investigadores creen que, además del prión, debe de haber otro agente infeccioso aún no identificado. Otros no descartan que aparezca un virus. Y otros están seguros de que la nueva enfermedad detectada en GB no es ECJ sino la propia EEB de las vacas. (El Mundo, 28/03/96) 
(8) Some researchers believe that, in addition to prion, there must be some other nonidentified agent of infection. Others do not rule out the possibility of a virus appearing. And others are sure that the new disease detected in GB is not ECJ, but none other than the EEB occurring in cows (El Mundo, 28/03/96)

In this example, scientist are presented in aggregation in terms of Van Leeuween (1996), identified as groups that show disagreement in the evolution of science research. This disagreement is also reflected in a variety of verbs indicating scientific debate and different points of view: in example 8 a positive expression "are sure" is used next to a tentative verb such as "believe".

Finally, "texts", a form of objectivization, are in this second phase a notable source for citation, being presented in a general determinate form or by the name of the publication, with no identification of authorship. Personal reference is lost through a metonymic reference (as "Studies" in example 9) that gives credibility to the written words -related to the accepted knowledge of the scientific community:

(9) Los estudios han demostrado que en ninguna de ellas [enfermedades neurodegenerativas], los leucocitos -el "ejército" del sistema inmune- se infiltran en el cerebro. (El Mundo, 28/03/96)

(9) Studies have demonstrate that in none of them [neurodegenerative diseases] do leucocytes - the immune system's "army" - infiltrate into the brain. (El Mundo, 28/03/96) 
Citations of texts are presented with significant research verbs such as "demonstrate" ("demostrar") in example 9 or "reveal" ("revelar").

As can be seen, in this second phase sources are heterogeneous, in their reference as well as in their mode of representation. Experts come from different fields: neurologists, biologists and microbiologists, veterinarians, etc. bringing about an expansion of information that complements the purely medical data. Journalists begin to quote research on microbiology, looking for a possible explanation of the causes of the infection, trying to confer credibility based on the results of studies.

\section{A. 3. Third phase: a scientific move}

This phase is typified by a particular instance of scientific communication as it appeares in the British journal Nature, about a month after the outbreak of diplomatic and economic conflict generated by the first wave of news. It represents progress made in scientific information.

We find different forms of representation of this source alone; a) as the text published in Nature, a form of objectivization exemplified in the following citation:

(10) Un estudio que publica hoy la revista Nature demuestra que la estructura genética de los priones de las vacas tiene un parecido muy significativo con los priones de los seres humanos. (El Mundo, 25/04/96)

(10) A study published today in Nature magazine demonstrates that the genetic structure of prions in cows is very significantly similar to prions in human beings. (El Mundo, 25/04/96) 
c) as the group of scientists who carried out the research, a mode of collectivization represented in example 11:

(11) Los científicos de Oxford, incluidos T.R.F. Southwood, antiguo miembro de la comisión asesora del Gobierno británico sobre la enfermedad de las vacas locas, han descubierto que estas proteínas [priones] de vacas y personas comparten dos rasgos distintivos en su estructura que están ausentes en la proteína de oveja. (El País, 25/04/96). (11) Scientists at Oxford, including T.R.F. Southwood, former member of the British government advisory commission on mad cows' disease, have discovered that these proteins [prions] in humans and cows share two distinctive traits in their structure that are absent in the sheep protein. (El Pais, 25/04/96)

d) and as the authorities on the matter, in the process of individualization expressed in example 12:

(12) "Las ovejas padecen una enfermedad similar desde hace doscientos años pero nunca se ha transmitido a las personas. La enfermedad de las vacas, en cambio, sí puede haberse transmitido. Si así es, debemos buscar una característica que tengamos en común con las vacas pero no con las ovejas. Y es precisamente lo que hemos encontrado", explicó ayer David Krakauer, director de la investigación, en entrevista telefónica. (La Vanguardia, 25/04/96)

(12) "For the last two hundred years, sheep have suffered a similar disease that has never been passed on to humans. The disease in cows does however seem to have been passed on 
to humans. If this is so, we have to look for a characteristic we have in common with cows but not with sheep. And that's precisely what we have found", explained David Krakauer, director of the investigation, yesterday in a telephone interview. (La Vanguardia, 25/04/96)

As we see in the examples above, reporting research verbs are frequently used: “demonstrates" ("demuestra" in example 10), "have discovered" ("han descubierto" in example 11), associated with the collective of researchers and with texts. Also, markers such as "for" ("según", "para"), which show a neutral position, are employed to introduce the group of scientists, and not only to refer to an individual authority (as in the second phase). Finally, the popularizing verb "to explain" ("explicar") is used in this third phase primarily in relation with authorities ("explained" in example 12).

Nevertheless, when scientist are quoted as a generic group, tentative reporting verbs are also assigned, as in the previous phases:

(13) Los científicos creen que [los priones] pueden causar graves enfermedades neurológicas cuando pasan de una especie a otra e incluso cuando pasan de un individuo a otro dentro de la misma especie. (La Vanguardia, 25/04/96)

(13) Scientists believe that [prions] can cause serious neurobiological illnesses when they pass from one species to another and even when they are passed from one individual to another within the same species. (La Vanguardia, 25/04/96)

To sum up, in the third phase, the source is a scientific article on microbiology published in one of the most prestigious reference journals in science communication (Nature). We 
cannot find any significant discourse function in the way scientific voices are represented, by individualization, collectivization or objectivization, since all of them are present in the quote frame referring to the same source. The reporting verbs used are in the semantic domain of research ("demonstrate", "discover", "conclude") and divulgation ("explain"), following the patterns of science communication. Moreover, markers of neutrality are used frequently to introduce scientific discourse.

\section{B. Contrasting scientific and non scientific voices}

As we have already mentioned, the proportion of speech reported from scientists in our selected corpus is only $21.57 \%$ of the total amount of reported speech; in other words, non scientific voices are dominant. For this reason it is interesting to contrast the representation of scientific and non scientific voices in order to note differences in the role and position of each kind of agent as featured in science communication.

In a previous study -reported in Calsamiglia \& López Ferrero (2001), Calsamiglia \& Cassany (2001)-, the respective contributions of scientific and non scientific voices in the information on "mad cows" disease are examined. The present analysis confirms the results presented in the two articles, in which we studied use of quotation in the three first days of diffusion of the news in the Spanish newspapers.

Table 2 shows the distribution of scientific voices in the present corpus in relation to the representation of identity:

\begin{tabular}{|c|c|c|c|}
\hline $\begin{array}{c}\text { Genericization } \\
(16.66 \%)\end{array}$ & $\begin{array}{c}\text { Assimilation } \\
(\mathbf{2 5 \%})\end{array}$ & $\begin{array}{c}\text { Individualization } \\
(\mathbf{4 3 . 7 5 \% )}\end{array}$ & $\begin{array}{c}\text { Objectivizati } \\
\text { on }(\mathbf{1 4 . 5 8} \%)\end{array}$
\end{tabular}




\begin{tabular}{|c|c|c|c|c|c|c|c|}
\hline \multirow[b]{2}{*}{$\begin{array}{l}\text { "Scientists" } \\
\text { "Experts" }\end{array}$} & \multirow[t]{2}{*}{$\begin{array}{l} \\
\text { Determined } \\
\end{array}$} & \multicolumn{2}{|c|}{$\begin{array}{l}\text { +Determin } \\
\text { ed }\end{array}$} & \multirow[t]{2}{*}{$\begin{array}{c}- \\
\text { Determined } \\
\end{array}$} & \multicolumn{2}{|c|}{ +Determined } & \\
\hline & & Gov & Res & & Author & WHO & \\
\hline 16 & 1 & 14 & 9 & 1 & 29 & 12 & 14 \\
\hline
\end{tabular}

Table 2. Presence and identity of scientific voices (96 citations: $21.57 \%$ )

Scientific voices are frequently put into a process of genericization, as a community without specific reference ("los científicos", "los expertos", etc.). When there is a process of assimilation two specific groups are represented: government advisors (Gov in table 2) and collectives of concrete researchers (Res), some of which publish their studies in Nature. As for individualization, this mode is presented through a scientific authority (Author) or a World Health Organization member $(W H O)$.

In contrast, the following table 3 shows the distribution of non scientific voices in the corpus: 


\begin{tabular}{|c|c|c|c|c|c|c|c|c|c|c|c|}
\hline \multicolumn{4}{|c|}{$\begin{array}{c}\text { Assimilation } \\
(27.79 \%)\end{array}$} & \multicolumn{7}{|c|}{$\begin{array}{c}\text { Individualization } \\
(70.20 \%)\end{array}$} & $\begin{array}{l}\text { Objectivizati } \\
\text { on }(2 \%)\end{array}$ \\
\hline $\begin{array}{c}- \\
\text { Determined } \\
\end{array}$ & \multicolumn{3}{|c|}{ +Determined } & & \multicolumn{6}{|c|}{+ Determined } & \multirow[t]{3}{*}{ 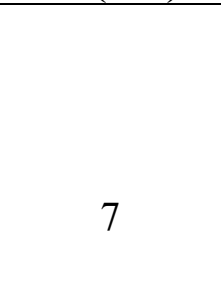 } \\
\hline \multirow[b]{2}{*}{12} & $\begin{array}{c}\mathrm{Co} \\
\mathrm{u}\end{array}$ & Inst & Org & & $\begin{array}{c}\mathrm{Ci} \\
\mathrm{t}\end{array}$ & Mer & Org & $\begin{array}{c}\text { Poli } \\
\mathrm{t}\end{array}$ & $\begin{array}{c}\text { Pres } \\
\mathrm{S}\end{array}$ & $\begin{array}{c}\text { Spe } \\
\text { c }\end{array}$ & \\
\hline & 17 & 41 & 27 & & 5 & 12 & 60 & 134 & 24 & 10 & \\
\hline
\end{tabular}

Table 3. Presence and identity of non scientific voices (349 citations: $78.43 \%$ )

\section{Abbreviations used in this table refer to the different forms of representations:}

Forms of assimilation:

- Cou: country ("Suiza, Alemania, los alemanes, Reino Unido, etc.")

- Inst: institution ("el gobierno, la Administración española, las autoridades suizas, la UE, etc.")

- Org: organization ("la Organización Mundial de la Salud, el sector cárnico, las organizaciones agrarias, los sindicatos agrícolas, etc.")

Forms of individualization:

- Cit: citizen ("dos oficinistas, un quiosquero, un ingeniero cincuentón, un ama de casa")

- Mer: merchant ("un carnicero, un exportador de carne, el encargado del restaurante, etc.")

- Org: organization ("un portavoz de la OMS, el presidente del Sindicato Nacional de Ganaderos, etc.")

- Polit: politician ("el ministro de la presidencia en funciones, el líder de la oposición laborista, etc.")

- Press: press ("Le Monde, The Daily Telegraph, EFE, special correspondents.")

- Spec: specialist ("sociólogo, antropólogo, etc."). 
Forms of objectivization: "informe, código penal, etc."

As shown, non scientific voices are represented mainly as individual voices $(70.20 \%)$, politicians being the social agents most cited. The data tells us how, in this case, politicians are called upon to provide information even on science matters. As for the reporting verbs used, the press attributes a positive ("assure" in example 14) and interaction-oriented position ("urge", "call" in examples 15 and 16) to social agents with a political function. In a critical situation, political actors are the ones expected to be active on their speeches, decision making, recommendations. They are pushed to perfom symbollically, involving sometimes a risk for their public face:

(14) Tony Blair, líder de la oposición laborista, también aseguró que continuará comiendo carne de buey, aunque acusó al Gobierno de "ocultar datos" a la opinión pública, y de "resistirse a decir toda la verdad" para proteger los intereses de los ganaderos. ( $L a$ Vanguardia, 22/3/96)

(14) Tony Blair, leader of the Labour opposition, also assured the House that he would continue eating beef, although he accused the Government of "hiding facts" from public opinion, and of "refusing to tell the whole truth", to protect the farmers' interests. (La Vanguardia, 22/03/96)

(15)Precisamente ayer, su presidente, Jacques Santer, reclamó a John Major medidas urgentes para acotar la crisis y permitir que la UE pueda levantar el embargo -siquiera parcialmente- que pesa sobre el vacuno británico.(El País, 25/4/96) 
(15) Precisely yesterday, its president, Jacques Santer, urged John major to take urgent measures to bring the crisis to an end and allow the EU to lift the embargo (partially) imposed on British beef. (La Vanguardia, 25/04/96)

(16) Un sector predominante de la prensa comparte esta tendencia. Sir Teddy Taylor, abanderado del euroescepticismo, pidió ayer una prohibición total de vino y queso francés en el Reino Unido en venganza por el boicot francés contra la carne británica. $(A B C, 23 / 3 / 96)$

(16) A major part of the press shares this tendency. Sir Teddy Taylor, avowed Eurosceptic, called yesterday for a total ban on French wine and cheese in the United Kingdom, in revenge for the French boycott on British meat (ABC, 23/03/96)

On the other hand, when we consider the generic and collective representation of scientific voices (40 citations) plus their objectivized representation as texts (14 citations), we observe that, unlike what we saw with non scientific voices, the predominant source is not an individual: "science" is represented by the scientific community as a group, or by texts. Therefore, the scientific community and texts are perceived by society as sufficent markers of authority. However, if we leave the 14 textual citations aside and focus on the 40 citations of personal scientific voices, the proportion of individualized (43.75\%) and generic and assimilated $(41.66 \%$ in total) citations are very close. A relevant feature is that both assimilated and individualized citations are presented in noun phrases (NPs) with determiner. In the case of individual voices, the determination is related to a personal social identity (name, status, etc.). In the case of generic and assimilated voices -"scientist" ("los científicos"), "experts" ("los expertos"), "researchers" ("los investigadores"), etc.- there is generally just a simple determiner preceding a common noun, having either an anaphoric or 
generalizing function; again the linguistic choice appeals to a "common ground" representation of the role of scientific work.

As for the reporting verbs, we find scientific and non scientific voices coincide in their use of positive and neutral verbs, such as "say", "state", "assure" ("decir", "afirmar", "asegurar"). Nevertheless, there is a relevant difference in the use of specific verbs in each kind of source. As we have noticed, reporting verbs assigned to non scientific voices can be described as interaction-oriented: " claim", "announce" ("reclamar", "anunciar"), while those assigned to scientific voices are content-oriented: "explain", "believe", "consider", "show", "emphasize" ("explicar", "creer", "considerar", "señalar", "destacar"), related to mental activities of knowledge, qualification and focalization. Some of them reflect a tentative position ("believe", "consider"), others ("explain", "show") are characteristic of popularizing discourse.

As a summary, in the following table we present the relevant contrasts in the forms of representation of identity and in the choice of reporting verbs to introduce scientific and non scientific speech:

\begin{tabular}{|l|l|l|}
\hline \multicolumn{1}{|c|}{ Voice } & \multicolumn{1}{|c|}{ Representation of identity } & Reporting verbs \\
\hline Non scientific & Assimilation & Positive and neutral \\
Individualization & Genericization \\
Scientific & Assimilation \\
& Individualization \\
& Objectivization & Positive and neutral \\
& Content oriented: tentative and \\
& popularizing \\
\hline
\end{tabular}


Table 4. Choice of representation of identity forms and reporting verbs 


\section{Discussion}

At the beginning of this paper, we posed several research questions about the sense, direction and effects of the insertion of words from scientific sources into journalist discourse. Our aim has been to reveal the role of scientific voices on an issue where they are entitled to talk, and to explain the orientation of discourse depending on the forms of quoting, above all in a situation of crisis such as the "mad cows" affair has been and is still continuing to be.

Another kind of question is related to the use that journalists make of citation: is quoted speech a way of erasing the responsibility of journalists or a means of orientating their position on the topic of reference? As Moirand (2000) points out, journalists compensate what she calls an "insecurité discursive" by bringing to their discourse the very many voices involved in the problem. By doing so they dramatize the conflict. At all events, the amount of quoting of non-scientific individuals, mainly politicians, indicates that responsibility is assigned to socio-political actors, even if the information has its origin a report made by a group of researchers.

Why are scientific voices so scarcely represented? Our proposed division of the journal articles studied into stages may help to give answers to this question. This procedure has been useful in allowing us to grasp the modulations suffered by information in the dynamics of the process of communication.

In our analysis, the first and second phases of the news story are just four days apart, while the third phase comes nearly a month later. The first phase is marked by the 
representation of scientists as a collective dependent on political directives (parliament, ministers, organizations). The scientific community is presented in the context of social life as a class that is expected to give quality information. The first problem arises: the demands of media information and the nature of scientific information collide. They reflect two ways of representing knowledge: science based on ongoing search, on the discussion of hypotheses, with no conclusive evidence; the media based on the idea that scientists are able to provide an account that will bring a quick solution to the problem.

The second phase is marked by diversification and individualization, while written studies are drawn upon also as a credible referent. A variety of experts and texts are called upon and according to the state of knowledge, still not established or accepted, different points of view are reported. This is a legitimate position in the context of science, but again the problem arises when it is presented to a public that needs to make urgent decisions, adding to the confusion created in the first phase.

The third phase is marked by the reference to a scientific source, the publication of a microbiology research article about the possible infectious agent of the disease. In this phase the standard way of communicating advances in science is respected. The progress in scientific information is presented and explained within its strict limits through the text and the group, only incidentally individualizing the research actors. But though it seems that some of the causes of the disease are beginning to be explained, in the context of social alarm and economical conflict this cannot fulfill the more immediate and urgent needs of the general public. 
As for the evaluative activity of journalists, it seems that the use of reported speech is a means of orientating their position on the topic of reference, as well as or even more than a way to erase their responsibility to inform objectivity. Journalists seem to assume that they reflect public needs and fears as well as the loss of control that a health crisis situation generates. If the scientific role is not considered a decisive social role capable of mitigating social alarm on its own, journalists are not able to assign or recognize the limits of scientific knowledge and to present such limits as a worthy fact in itself. On a public level, the consequence is that this knowledge is used as a source of confusion rather than a contribution to the understanding of the problem.

\section{Conclusion}

As a conclusion we can say that the analysis of the "quoting frame", in its canonical components of agent identity and reporting verbs, gives a representation of what the press considers relevant for that part of information which is based on words, not on facts. The most outstanding feature is that multiple voices are called upon for the clarification of a situation where decisions have to be taken at different levels. In point of fact, the "mad cows" affair is an example of the propagation of ongoing research through political instance. The circulation of information generated in a research context, once put in different contexts, may create the confusion that we have been able to describe in the analysis of the choice of reporting verbs, showing different attitudes, understanding and interests.

The study of the "mad cows" case shows the differing pace of science and daily life as a décalage that is manifested through the way the press, reacting consciously or unconsciously to a situation of crisis, gives rise to different voices. Scientific voices have a limited role in the press, much less weight than those of political actors. Individual scientific authorities 
(researchers) are presented in a lower proportion than scientists as a generic class or in a civic/administrative role. As for the communicative position, journalists attribute a neutral and popularizing stance to individual researchers and a controversial and tentative position to the scientist in general, both of these contrasting with the positive, interaction-oriented position attributed to the social agents with a political function.

The position assigned to scientists is a qualified one but not efficient enough, managing a kind of knowledge a) that rests on tentative hypotheses and questions under research and b) whose advances do not give rise to results with immediate answers to social needs. In fact, the two representations of knowledge show their contradictions when they are placed side by side: the scientific representation (science domain) and the social representation (society domain). A question remains unanswered: whether confidence in scientific work can be maintained in the media even if what is communicated is the limited state of knowledge.

These conclusions should be contrasted with the analysis of the role and position of scientific voices in the new "mad cows" episode which has peaked at the turn of the century. Approximately five years after the first appearance of the story in the media, a new episode of the crisis has been developing. Following this rich communicative event should provide ways of accounting for journalists' responsibility in representing science in social life and their contribution of a better public understanding of science. 


\section{NOTES}

1. This is the final version of a study carried out under the auspices of DGES project $n^{\circ}$ PB96-0292. "Análisis discursivo de la divulgación científica: aspectos pragmáticos, textuales y retóricos" as part of the program of the Dirección General de Enseñanza Superior del Ministerio de Educación y Cultura (1997-2000) of the Spanish Government, and presented as a paper at the VII International Pragmatics Conference of Budapest (2000). A first version was originally presented as work in progress at the $I$ Simposio Internacional de Análisis del Discurso, Madrid, 1998 (see Calsamiglia \& López Ferrero 2001 and Calsamiglia \& Cassany 2001).

2. D1 refers to main discourse by writer 1 (W1); D2, to quoted discourse by writer 2 (W2).

3. An exhaustive classification of reporting verbs has been proposed by Battaner et al. (2001): assertive communicative ("decir, comunicar, preguntar, asegurar, prometer, manifestar, admitir"), claim communicative ("asegurar, recalcar, insistir, reiterar, precisar, puntualizar"), attention focus ("observar, señalar, ver, reflejar, advertir, indicar, destacar"), positive evaluation ("alabar, elogiar, aprobar, dar importancia, destacar, subrayar. recalcar"), negative evaluation ("reprochar, desaprobar, criticar, acusar, lamentar, atacar, descartar"), demanding ("pedir, ordenar, mandar, prohibir, exigir, aconsejar, instar a, suplicar, reclamar, solicitar"), forms of speech ("susurrar, tartamudear, suspirar, gritar, exclamar, chillar, carcajearse, reírse, gruñir, murmurar, declamar, tararear, cantar, recitar"), discourse markers ("empezar, comenzar, añadir, seguir, acabar, terminar, continuar, concluir"), discourse action description ("comentar, desarrollar, considerar, plantear, proponer, tratar, sostener, confesar"), interaction description ("intervenir, responder"), metalinguistic markers ("narrar, citar"), opinion verbs ("opinar, juzgar, considerar, creer, dar su opinión, estar convencido de, calificar, 
sugerir, estimar"), counter argumentative ("discutir, objetar, rectificar"), analysis ("analizar, distinguir, establecer, hacer una distinción"), comparison ("comparar, ejemplificar"), thinking and observing ("pensar, especular, sentir, ver, oír").

4. The analysis of citation in the three first days in those newspapers at the moment when it became known that BSE might be transmitted to the human species has been studied in Calsamiglia \& López Ferrero (2001).

5. In the examples, we stress in boldface font the linguistic structures (the pre-citations) analysed.

\section{REFERENCES}

Abc (1993) Libro de estilo, Barcelona, Ariel.

Authier-Revuz, J. (1982) " Hétérogénéité montrée et hétérogénéité constitutive: éléments pour une approche de l'autre dans le discours", DRLAV, 26, pp.91-151.

Bajtin, M.M. (1979) Estética de la creación verbal. México, D.F. Siglo XXI

Battaner, M.P. et al. (2001). Aprender y enseñar: La redacción de exámenes. Madrid: Antonio Machado Libros, S.A.

Benveniste, É.(1971) Problemas de lingüística general I. Mexico City: Siglo XXI

Benveniste, É. (1974) Problemas de lingüistica general II. Mexico City: Siglo XXI, 1977

Caldas-Coulthard, C. R. (1994) "On reporting reporting: the representation of speech in factual and factional narratives." M. Coulthard (ed) Advances in Written Text Analysis London: Routledge, pp.295-308.

Calsamiglia, H.; Cassany, D. (2001) "Voces y conceptos en la divulgación científica" en: Revista Argentina de Lingüistica, Vol. 11-15, pp. 173- 208. Buenos Aires. 
Calsamiglia, H. \& López Ferrero, C. (2001). "Polifonía en textos periodísticos con información científica". In J. Garrido Medina (coord.) Lengua, discurso, texto (I Simposio Internacional de Análisis del Discurso). Madrid: Visor Libros, pp.2647-2664.

Charaudeau, P. (1997) Le discours d'information médiatique. La construction du miroir social. Paris: Nathan.

Daban, M. \& Grau, M. (1996) “La enfermedad de las vacas locas; análisis de los fenómenos científicos y mediáticos" Quark 5, pp.11-18

Donadieu, J. (1997): "El complejo asunto de las vacas locas. Por una lectura crítica de los raros datos científicos disponibles" Mundo científico 185, pp.1008-1010

Ducrot, O. (1984) "Esbozo de una teoría polifónica de la enunciación". In El decir y lo dicho. Polifonía de la enunciación, Barcelona: Paidós,1986, pp.174-238.

Girón Alconchel, J. L. (1989) Las formas del discurso referido en el "Cantar de Mío Cid", Madrid. Anejos del Boletín de la Real Academia Española, Anejo XLIV.

Haverkate, H. (1996) "Modal patterns od direct and indirect discourse in Peninsulare Spanish: An analysis within the framework of speech act typology" in: Janssen, T.A J; Van der Wurff, W. (eds.) (1996) Reported Speech: Forms and Functions of the Verb. Amsterdam: John Benjamins.

Hyland, K. (2000) "Academic attribution: interaction through citation". In Disciplinary discourses. Social interaction in academic writing London: Longman, pp20-40.

Informe Quiral. Publicaciones del Observatorio de la Comunicación Científica. Barcelona: Universidad Pompeu Fabra.

Janssen, T.A J; Van der Wurff, W. (eds.) (1996) Reported Speech: Forms and Functions of the Verb. Amsterdam: John Benjamins. 
Jasanoff, Sh. (1997) "Civilization and madness: the great BSE scare of 1996". Public Understanding of Science 6, pp.221-223.

Kerbrat-Orecchioni, C. (1980) L'Énonciation de la subjectivité dans le langage. París: Armand Colin.

Krakauer, D.C., Pagel, M., Southwood, T.R.F. y Zanotto, P.M. (1996) "Phylogenesis of prion protein". Nature, $380, \mathrm{n}^{\circ} 6576$.

Lucy, J.A. (ed) (1993) Reflexive Language. Reported Speech and Metapragmacity. Cambridge: Cambidge University Press.

Maingueneau, D. (1987) "L'hétérogénéité". In Nouvelles tendances en analyse du discours Paris: Hachette, pp. 53-93.

Maingueneau, D. (1991) L'Énonciation en linguistique française embrayeurs, "temps", discours rapporté. París: Hachette.

Maingueneau, D. (1993) Éléments de linguistique pour le texte littéraire. París: Dunod.

Maldonado, C. (1991) Discurso directo y discurso indirecto. Madrid: Taurus.

Maldonado, C. (1999) "Discurso directo y discurso indirecto".In I. Bosque y V. Demonte (dirs.) Gramática descriptiva de la lengua española Madrid: Espasa Calpe, pp.35513595.

Moirand, S. (1997) "Formes discursives de la difussion des savoirs dans les médias", Hermès, 21 (Sciences et médias), pp. 33-44.

Moirand, S. (2000) "Variations discursives dans deux situations productrices d'un discours sur la science de la presse ordinaire" Carnets $d u$ Cediscor 6. Paris: Université de la Sorbonne Nouvelle.

Méndez García de Paredes, E. (1999a) "La literalidad de la cita en los textos periodísticos". In Garrido Medina, J. (ed.) (1999). La lengua y los medios de comunicación. Actas del 
Congreso Internacional celebrado en la Universidad Complutense de Madrid en 1996,

Madrid: Servicio de Publicaciones de la Universidad Complutense de Madrid, pp. 129148. Artículo publicado en Revista Española de Lingüística, 30.1, pp. 147-167.

Méndez García de Paredes, E. (1999b) "Análisis de la reproducción del discurso ajeno en los textos periodísticos", in Pragmalingüística, 7, pp.99-128.

Porta, M. (1996) "Pasando la maroma con John Major a cuestas.Apuntes imaginarios sobre la implausible responsabilidad de una sociedad científica ante la inverosímil crisis de las “vacas locas” Quark 5, pp.19-32

Ratzan, S.C. (ed) (1998) The Mad Cow Crisis. Health and the Public Good. NY: New York University Press

Reyes, G. (1993) Los procedimientos de cita: estilo directo y estilo indirecto, Madrid, Arco Libros.

Reyes, G. (1994) Los procedimientos de cita: citas encubiertas y ecos. Madrid: Arco Libros

Thomas, S. \& Hawes, T. (1994) "Reporting verbs in medical journal articles" English for Specific Purposes, vol 15, n², pp.129-148.

Van Leeuwen, T. (1996) "The representation of social actors" in Carmen Rosa CaldasCoulthard y M. Coulthard (eds) Texts and practice. London: Routledge.

Van Dijk, Teun A. (1988) News as discourse Lawrence Erlbaum Ass.

Voloshinov, V.N. (1929). El Marxismo y la filosofía del lenguaje. Madrid: Alianza Editorial, 1992.

Waugh, L. (1995) "Reported speech in journalistic discourse: the relation of function and text" Text 15 (1), pp.129-173.

Will, R.G., Ironside, J.W. et al. (1996) "A new variant of Creutzfeld Jakob disease in UK". Lancet, 347, $\mathrm{n}^{\circ} 9006$. 
Zander, U. (1997) Le journaliste, le scientifique, et la vache folle. Paris: Publications de l’Université. Paris VII 